\title{
Comparative Study of the Phytochemistry and Antioxidant Activity of Anacardium occidentale (L.) Leaf and Stem Bark Extracts
}

\author{
Issiaka Togola ${ }^{1,}$, Youssouf Kaya $^{1}$, Nouhoum Diarra ${ }^{1}$, Mamadou Abdoulaye Konare ${ }^{2}$, \\ Adama Denou ${ }^{2,3}$, Rokia Sanogo \\ ${ }^{1}$ Département de Biologie, Faculté des Sciences et Techniques (FST), Université des Sciences, des Techniques et des Technologies de Bamako \\ (USTTB), Bamako, Mali \\ ${ }^{2}$ Department of Pharmacognosy and Traditional Medicine, University of Jos, Jos, Nigeria \\ ${ }^{3}$ Department des Sciences Pharmaceutiques et de Médicine Traditionnelle, Université des Sciences, des Techniques et des Technologies de \\ Bamako (USTTB), Bamako, Mali
}

\section{Email address:}

togola3@gmail.com (I. Togola), youssoufkaya@gmail.com (Y. Kaya), nouhoumdiarra2002@yahoo.fr (N. Diarra), konaresucces@gmail.com (M. A. Konare), denouadamab@gmail.com (A. Denou), rosanogo@yahoo.fr (R. Sanogo)

${ }^{*}$ Corresponding author

\section{To cite this article:}

Issiaka Togola, Youssouf Kaya, Nouhoum Diarra, Mamadou Abdoulaye Konare, Adama Denou, Rokia Sanogo. Comparative Study of the Phytochemistry and Antioxidant Activity of Anacardium occidentale (L.) Leaf and Stem Bark Extracts. Journal of Diseases and Medicinal Plants. Vol. 6, No. 3, 2020, pp. 72-76. doi: 10.11648/j.jdmp.20200603.13

Received: August 31, 2020; Accepted: September 15, 2020; Published: September 23, 2020

\begin{abstract}
The use of plant roots and stem barks is a common practice in traditional medicine. This practice could lead to the disappearance of some plant species. Anacardium occidentale (L) is a plant whose stem bark is commonly used for the traditional management of diabetes and hypertension in Mali. In the hope of replacing this organ with the leaves, a comparative phytochemical study of the two organs was carried out. The Phytochemical screening was carried out through colouring and precipitation reactions. The Folin-Ciocalteu reagent was used to determine the content of total phenolic compounds whereas the flavonoids were determined using aluminium trichloride. Antioxidant activity was evaluated by the TAC and DPPH methods. The results obtained have shown that both organs were rich in secondary metabolites with a similar phytochemical profile. Also, it was found that regardless of the solvent used, the leaves contained the highest levels of total phenols and flavonoids. Thus, the contents of total phenols in methanolic extracts have been $211.2 \pm 21.8 \mathrm{mg} \mathrm{GAE} / \mathrm{g}$ and $129.72 \pm 5.15 \mathrm{mg}$ GAE$/ \mathrm{g}$ for leaves and stem barks respectively. As for those of flavonoids, they have been $59.02 \pm 5.88 \mathrm{mg} \mathrm{QE} / \mathrm{g}$ for leaves and $31.30 \pm 2.74 \mathrm{mg} \mathrm{QE} / \mathrm{g}$ for stem barks. However, the stem barks showed the higher antioxidant activity than the leaves, which is also appreciable. In sum, other studies such as toxicological one must be conducted before replacing stem barks with leaves in the traditional management of these two pathologies.
\end{abstract}

Keywords: Anacardium occidentale, Phytochemistry, Antioxidant Activity, Leaf and Stem Bark

\section{Introduction}

African populations are facing the emergence of diabetes and high blood pressure (hypertension), diseases that are said to be new to traditional African medicine [1]. In Sub-Saharan Africa, the prevalence of hypertension is high among adults aged 18 years and older, ranging from $16 \%$ to $40 \%$. In some studies, the prevalence exceeds $60 \%$ among people aged 65 years and older [2]. In 2013, there were 19.8 million people with diabetes, and this number is expected to increase to 41.4 million in 2035 [3]. In Mali, these two pathologies are increasingly becoming a real public health problem. Indeed, the prevalence of hypertension varies according to the studies from $20.83 \%$ to $39.4 \%$ [4]. According to the International Diabetes Federation, in 2019 in the 20-79 age group, there were 2,669 deaths due to the diabetes in the country and the number of people living with diabetes was 157,600 [5]. The treatment and monitoring of these diseases is an additional economic problem. In addition, there is a lack of specialists 
in the area, remoteness, the scarcity or absence of health centres in villages, and the unavailability and excessive cost of pharmaceutical products [6]. More than $80 \%$ of the population uses medicinal plants for health care $[7,8]$. Anacardium occidentale, a plant belonging to the Anacardiaceae family, is frequently used by the African population in the management of diabetes and hypertension $[6,9,10,1]$. In Mali, the stem barks of the plant are the most appreciated organs and this practice is not safe for the plant. Indeed, the debarking of the plant has harmful effects such as blocking the transport of sap, increasing the risk of insect attack and limiting the plant's survival rate [11]. Moreover, the method of harvesting of stem bark and the increased it use by the population make the species more threatened with extinction [12]. In the hypothesis that the stem barks of Anacardium occidentale could be substituted by its leaves, in the interest of preserving biodiversity, this work was carried out in order to compare the phytochemical compositions, as well as the antioxidant activity of the different extracts of the stem barks and leaves of this plant.

\section{Material and Methods}

The plant material used was the stem barks and the leaves of Anacardium occidentale harvested at Tousséguéla in Mali, coordinates are $11^{\circ} 03^{\prime} 14^{\prime \prime}$ 'North, $6^{\circ} 35^{\prime} 10^{\prime \prime}$ West. The samples were identified at the Laboratory of Tropical Ecology, University of Sciences, Techniques and Technologies of Bamako.

\subsection{Preparation of Extracts}

Twenty-five grams of powder of each organ (stem barks and leaves) were dissolved by magnetic stirring for $48 \mathrm{~h}$ at $30^{\circ} \mathrm{C}$ in $250 \mathrm{ml}$ of different solvents (Methanol, Water and Ethyl Acetate). After filtration of the resulting mixture, the solvent was evaporated under reduced pressure. The dried extracts were recovered and stored in the freezer for analyses.

\subsection{Phytochemical Screening}

The extracts were analysed to highlight the different phytochemical groups. The protocols described by Harborne and Srivastava et al, $[13,14]$ were used to carry out this work.

\subsection{Dosage of Total Polyphenols}

The contents of phenolic compounds in the different extracts of Anacardium occidentale were estimated by the Folin-Ciocalteu method described by Singleton et al, [15]. Thus, $500 \mu \mathrm{L}$ of Folin-Ciocalteu reagent (diluted 10\% in distilled water) is added to $100 \mu \mathrm{L}$ of extract and $400 \mu \mathrm{L}$ of disodium carbonate $\left(\mathrm{Na}_{2} \mathrm{CO}_{3}\right)$ at $75 \mathrm{mg} / \mathrm{mL}$ was added to the reaction mixture. After an incubation of 2 hours at room temperature and protected from light, the absorbance was read at $765 \mathrm{~nm}$. A calibration curve was performed under the same operating conditions using a gallic acid dilution series. The results were expressed in milligram equivalent of gallic acid per gram of extract (mgGAE/g).

\subsection{Dosage of Total Flavonoids}

The estimation of total flavonoids was carried out according to the method described by Chang et al, [16]. To $1000 \mu \mathrm{L}$ of each extract to be analysed, $1500 \mu \mathrm{L}$ of $95 \%$ methanol, 100 $\mu \mathrm{L}$ of $10 \% \mathrm{AlCl}_{3}(\mathrm{w} / \mathrm{v}), 100 \mu \mathrm{L}$ of $1 \mathrm{M}$ sodium acetate and 2.8 $\mathrm{mL}$ of distilled water were added. The mixture was stirred and incubated in the dark at room temperature for $30 \mathrm{~min}$. The blank was made by replacing the extract with $95 \%$ methanol and the absorbance was measured at $415 \mathrm{~nm}$ using a UV spectrophotometer. The results were expressed in $\mathrm{mg}$ quercetin equivalent per gram of dry weight.

\subsection{Antioxidant Activity}

The DPPH radical scavenging test and the phosphomolybdate test were used to evaluate in vitro the antioxidant activity of the different extracts.

\subsubsection{DPPH Radical Scavenging Activity}

The ability to trap the stable free radical 1,1-diphenyl 2-picrylhyorazyl (DPPH) of Anacardium occidentale stem barks and leaves extracts was evaluated using the spectrophotometric method described by Brand-Williams et al., [17]. Briefly $1 \mathrm{~mL}$ of $0.1 \mathrm{mM}$ DPPH solution in methanol was mixed with $1 \mathrm{~mL}$ of extract at various concentrations (2-12 $\mu \mathrm{g} / \mathrm{mL})$. At the same time, a mixture of $1 \mathrm{~mL}$ methanol and $1 \mathrm{~mL}$ DPPH solutions was used as a control. The reaction was performed in triplicate and the decrease in absorbance was measured at $517 \mathrm{~nm}$ after 30 minutes incubation of the samples in the darkness. The positive control was ascorbic acid whose absorbance was measured under the same conditions as the samples. The antioxidant activity related to the scavenging effect of the DPPH radical is expressed as percentage inhibition (PI) calculated from absorbances obtained according to the following formula:

$$
[\mathrm{PI}]=\left[\mathrm{A}_{0}-\mathrm{A}_{1}\right] / \mathrm{A}_{0} \times 100
$$

$\mathrm{A}_{0}=\mathrm{DPPH}$ absorbance; $\mathrm{A}_{1}$ : sample absorbance.

$\mathrm{IC}_{50}$ (concentrations that inhibit $50 \%$ of the DPPH radical) were inferred from the linear regression line obtained from the graph representing the percentage inhibition of DPPH.

\subsubsection{Phosphomolybdate Test or Total Antioxidant Capacity ( $T A C)$}

The total antioxidant capacity was determined using the spectrophotometric method described by Prieto et al. [18]. Thus, to $1 \mathrm{ml}$ of extract at concentrations ranging from 10 to $100 \mu \mathrm{g} / \mathrm{ml}$ was added the reagent composed of $\mathrm{H}_{2} \mathrm{SO}_{4}(600$ $\mathrm{mM}), \mathrm{NaH}_{2} \mathrm{PO}_{4}(28 \mathrm{mM})$ and ammonium molybdate $(4 \mathrm{mM})$. The tubes were then incubated in a water bath at $95^{\circ} \mathrm{C}$ for 90 minutes. After cooling at room temperature, the absorbance was read at $695 \mathrm{~nm}$. Ascorbic acid was used as standard and antioxidant capacity was expressed in $\mathrm{mg}$ ascorbic acid equivalent per gram of dry weight (mgAA/g DW).

\subsection{Data Analysis}

The data obtained were processed using Excel® version 
2013 and Minitab 18.1 software. Analyses were run in triplicates and the results were expressed as mean values with standard error mean. The one ANOVA test using the Fisher's test was chosen to compare the levels of polyphenols, flavonoids and antioxidant activity of different types of extracts (ethyl acetate, water and methanol) from the stem barks and the leaves of Anacardium occidentale. P-values less than 0.05 were considered statistically significant.

\section{Results and Discussion}

\subsection{Phytochemical Screening}

The Table 1 presents the results of the phytochemical screening of the different extracts from the stem barks and leaves of Anacardium occidentale. The table shows the presence of alkaloids in the stem bark extracts (aqueous and methanol extracts) and in the methanol leaf extract. The absence of tannins was found in the aqueous and methanol leaf extracts. The flavonoids and coumarins were detected in all tested samples. Except the aqueous extracts of the two organs, the terpenoids were observed in the other samples. The saponins were absent in the methanol stem bark extract and the ethyl acetate leaf extract while their presence was observed in the other plant extracts. According to the Table 1 the phytochemical profile of the two organs (stem barks and leaves) of Anacardium occidentale are almost similar. Our findings are close to those of some previous work [19-21]. According to Ifesan et al [22], the presence of these bioactive compounds in the organs of Anacardium occidentale is a strong indication that this plant has medicinal potency. Indeed, many studies have shown that the secondary metabolites contained in Anacardium occidentale extracts have hypoglycemic and anti-hypertensive effects [23-25].

Table 1. Phytochemical screening of Anacardium occidentale stem bark and leaf extracts.

\begin{tabular}{lllllll}
\hline Chemical & \multicolumn{2}{l}{ Stem bark } & \multicolumn{5}{c}{ Leaf } \\
\hline Groups & EAE & WE & ME & EAE & WE & ME \\
\hline Alkaloids & - & + & + & - & - & + \\
Tannins & + & + & + & + & - & - \\
Flavonoids & + & + & + & + & + & + \\
Coumarins & + & + & + & + & + & + \\
Terpenoids & + & - & + & + & - & + \\
Saponins & + & + & - & - & + & + \\
\hline
\end{tabular}

Legend: $+=$ positive. $-=$ negative. $\mathrm{EAE}=$ Ethyl acetate extract. WE=Water extract. $\mathrm{ME}=$ Methanol extract.

\subsection{Total Polyphenol and Flavonoid Contents}

The levels of total phenolic compounds and flavonoids in the different types of stem bark and leaf extracts are shown in the Tables 2 and 3. Thus, the maximum of total phenolic compounds were obtained with the methanol extract from the leaves $(211.2 \pm 21.8 \mathrm{mgGAE} / \mathrm{g})$ and the minimum with the aqueous extract from the stem barks $(77.70 \pm 1.06 \mathrm{mg} \mathrm{GAE} / \mathrm{g})$. The results in Table 2 showed that overall there is a significant difference between the samples $(\mathrm{p}=2.09 \mathrm{E}-8)$ and regardless of the solvent used, Anacardium occidentale leaves are richer in total polyphenols than stem barks.

Table 2. Total phenol contents of Anacardium occidentale stem bark and leaf extracts.

\begin{tabular}{lll}
\hline \multirow{2}{*}{ Solvents } & \multicolumn{2}{l}{ Total phenol (mg GAE/g) } \\
\cline { 2 - 3 } & Stem bark & Leaf \\
\hline Ethyl Acetate & $99.53 \pm 0.84^{\mathrm{c}}$ & $138.47 \pm 6.27^{\mathrm{b}}$ \\
Water & $77.70 \pm 1.06^{\mathrm{d}}$ & $96.82 \pm 7.14^{\mathrm{c}}$ \\
Methanol & $129.72 \pm 5.15^{\mathrm{b}}$ & $211.2 \pm 21.8^{\mathrm{a}}$ \\
\hline
\end{tabular}

* For each parameter, the averages of each row that do not share any letters are significantly different at the threshold of 0.05 .

Table 3. Flavonoids contents of Anacardium occidentale stem bark and leaf extracts.

\begin{tabular}{lll}
\hline \multirow{2}{*}{ Solvents } & \multicolumn{2}{l}{ Flavonoids $(\mathbf{m g ~ Q E} / \mathbf{g})$} \\
\cline { 2 - 3 } & Stem bark & Leaf \\
\hline Ethyl Acetate & $32.49 \pm 0.53^{\mathrm{d}}$ & $44.09 \pm 2.46^{\mathrm{b}}$ \\
Water & $25.02 \pm 2.49^{\mathrm{e}}$ & $36.74 \pm 1.32^{\mathrm{c}}$ \\
Methanol & $31.30 \pm 2.74^{\mathrm{d}}$ & $58.64 \pm 2.62^{\mathrm{a}}$ \\
\hline
\end{tabular}

* For each parameter, the averages of each row that do not share any letters are significantly different at the threshold of 0.05 .

Table 3 provides information on the levels of flavonoids in the leaves and stem barks of Anacardium occidentale. It shows that with the solvents used, the leaves performed the highest flavonoid contents while the stem barks exhibited the lowest values. Overall, there is a significant difference in flavonoid levels $(p=4.7 \mathrm{E}-9)$. This fact has already been shown for total polyphenol contents. In this study, the results obtained with total polyphenols and flavonoids are different from those reported in previous studies [26-28]. This may be related to the genetic variation and geographical origins of the plant species [29].

\subsection{In Vitro Antioxidant Activity}

\subsubsection{DPPH Radical Scavenging Activity}

Figure 1 shows that the different extracts from leaves and stem barks of Anacardium occidentale have antioxidant activities. The highest activity of the barks was observed with ethyl acetate extract with an $\mathrm{IC}_{50}$ of $5.24 \pm 0.34 \mu \mathrm{g} / \mathrm{ml}$. For leaves, methanol and ethyl acetate extracts have shown similar antioxidant activity $(\mathrm{p}=0.169)$.

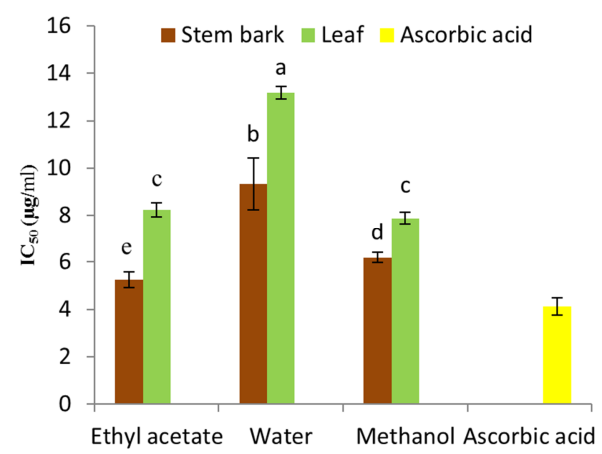

Figure 1. Reduction capacity of the DPPH radical expressed in $I C_{50}(\mu \mathrm{g} / \mathrm{ml})$ as a function of the organs and the extraction solvent.

*Each value is expressed as a mean \pm standard error. The bar charts for each extract with different letters are significantly different $(\mathrm{p}<0.05 ; \mathrm{n}=3)$. 
In 2016, a study conducted by Da Silva et al, [30] showed that Anacardium occidentale stem barks and leaves have the similar antioxidant activity with IC50 of $1.12 \mu \mathrm{g} / \mathrm{mL}$ and $1.47 \mu \mathrm{g} / \mathrm{mL}$, respectively. However, the findings of Sija et al [31] have shown that the young leaves have a higher antioxidant activity than stem barks.

\subsubsection{Total Antioxidant Capacity (TAC)}

In addition to the DPPH method, the antioxidant activity was evaluated by the phosphomolybdenum reduction test. Therefore, the total antioxidant capacity of the different leaf and stem bark extracts of Anacardium occidentale is summarized in the Table 4.

Table 4. Total antioxidant capacity of Anacardium occidentale stem bark and leaf extracts.

\begin{tabular}{lll}
\hline \multirow{2}{*}{ Solvents } & \multicolumn{2}{c}{ Total antioxidant capacity $(\mathbf{m g}$ AAE/gDW) } \\
\cline { 2 - 3 } & Stem bark & Leaf \\
\hline Ethyl Acetate & $92.81 \pm 1.83^{\mathrm{a}}$ & $54.34 \pm 2.93^{\mathrm{c}}$ \\
Water & $37.83 \pm 1.26^{\mathrm{e}}$ & $18.12 \pm 1.23^{\mathrm{f}}$ \\
Methanol & $79.36 \pm 1.89^{\mathrm{d}}$ & $49.85 \pm 3.05^{\mathrm{d}}$ \\
\hline
\end{tabular}

* For each parameter, the averages of each row that do not share any letters are significantly different at the threshold of 0.05

Data analysis showed a significant difference between the samples $(p=2.3 \mathrm{E}-13)$. Ethyl acetate extracts exhibited the best antioxidant activities $(92.81 \pm 1.83 \mathrm{mg}$ EAA $/ \mathrm{gDW}$ and $54.34 \pm 2.93 \mathrm{mg} \mathrm{EAA} / \mathrm{gDW}$ for stem barks and leaves respectively). The water extract showed the lowest values with $37.83 \pm 1.26 \mathrm{mg} \mathrm{EAA} / \mathrm{gDW}$ for the stem bark and $18.12 \pm 1.23 \mathrm{mg} \mathrm{EAA} / \mathrm{gDW}$ for the leaves, the aqueous extracts of Anacardium organs showed low TAC. The different trends observed with DPPH radical scavenging was confirmed by this second method. The different stem bark extracts showed higher antioxidant activities than leaf extracts $(p<0.05)$. Also for each organ considered, ethyl acetate extracts showed the strongest antioxidant activities. According to some authors, the antioxidant power of Anacardium occidentale depends on the extraction solvent [32-34]. For others, the antioxidant activity of Anacardium occidentale could be attributed to its phenolic constituents $[30,35]$. However, this study has shown that the antioxidant activity of Anacardium occidentale is not only due to the activity of phenolic compounds. Indeed, the leaves had the highest levels of total phenolic compounds and flavonoids while the best antioxidant activity was observed in the stem barks. That may explain the preference for stem barks by the patients with diabetes and hypertension. However, in Chad and Cameroon the leaves of this plant are also used in the traditional management of these two diseases [6,9]. It is necessary to note that both organs have proven antioxidant activity according to this study.

\section{Conclusion}

In this study, a phytochemical comparison of Anacardium occidentale leaves and stem barks was carried out. The screening of the extracts showed that the two organs have a similar phytochemical profile. Leaves have the highest levels of total phenols and flavonoids. The antioxidant activity determined by the TAC and DPPH methods have indicated that the two organs have an appreciable reducing power and that the antioxidant activity of the stem barks is significantly higher. The results from the current work revealed that Anacardium occidentale leaves could be a potential source of antioxidant molecules. Our findings have shown that the leaves could validly replace the stem barks. That could be helpful for protecting better this species from an eventual extinction. However, more research is needed before advising the leaves in the management of diabetes and hypertension.

\section{References}

[1] Tra Bi F H, Irié G M, N'gaman K C C, Mohou C H B. 2008. Études de quelques plantes thérapeutiques utilisées dans le traitement de l'hypertension artérielle et du diabète: deux maladies émergentes en Côte d'Ivoire. Sciences \& Nature. 5 (1): $39-48$.

[2] Houehanou C, Amidou S, Preux P M, Houinato D and Lacroix P. 2018. Hypertension artérielle (HTA) en Afrique subsaharienne. JMV-Journal de Médecine Vasculaire 43 (2).

[3] Diop S N, Diédhiou D. 2015. Le diabète sucré en Afrique sub-saharienne: aspects épidémiologiques et socioéconomiques. Médecine des maladies Métaboliques. 9 (2): 123-129.

[4] Menta I, Ba HO, Sanogo KM. Hypertension (HTA) among young people of 18 to 35 years old in cardiology department of Gabriel Touré university teaching hospital. World Journal of Cardiovascular Diseases. 2018; 8 (1): 11-17.

[5] IDF DIABETES ATLAS, Ninth edition 2019/AFRIQUE.

[6] Dongock D N, Bonyo A L, Mapongmestem P M, Bayegone E. 2018. Etude ethnobotanique et phytochimique des plantes médicinales utilisées dans le traitement des maladies cardiovasculaires à Moundou (Tchad). International Journal of Biological and Chemical Sciences. 12 (1), 203-216.

[7] Jiofack T., Fokunang C., Guedje N. M., Kemeuze V., Fongnzossie E., Nkongmeneck B. A, Mapongmetsem P. M., and Tsabang, N. 2010. Ethnobotanical uses of medicinals plants of two ethnoecological regions of Cameroon. International Journal of Medicine and Medical Sciences 2 (3): 60-79.

[8] Mpondo M. E., Dibong D. S., Priso R. J., Ngoye A., Ladoh Y C. F. 2012. État actuel de la médecine traditionnelle dans le système de santé des populations rurales et urbaines de Douala (Cameroun). Journal of Applied Biosciences 55: 4036-4045.

[9] Nole T, Lionel T D W, Cedrix T F S and Gabriel AA. 2016. Ethnomedical and Ethnopharmacological Study of Plants Used For Potential Treatments of Diabetes and Arterial Hypertension by Indigenous People in Three Phytogeographic Regions of Cameroon. Diabetes Case Reports. 1: 110.

[10] Bio A, Toyi S. S. M, Yoka J, Djego G. J, Awede B, Laleye A, Sinsin A. B. 2015. Contribution aux connaissances des principales plantes antihypertensives utilisées en médecine traditionnelle à Bassila (Bénin, Afrique de l'Ouest). Revue CAMES - Série Pharm. Méd. Trad. Afr.; 17 (2): 8-18. 
[11] Delvaux C, Sinsin B, Darchambeau F, Van Damme P. 2009 Recovery from bark harvesting of 12 medicinal tree species in Benin, West Africa. J. Appl. Ecol., 46, 703-712.

[12] Mbinile S D, Munishi L K, Ngondya I B and Ndakidemi P A. 2020. Conservation and Management Challenges Facinga Medicinal Plant Zanthoxylum chalybeum in Simanjiro Area, Northern Tanzania. Sustainability. 12, 4140.

[13] Harborne J. B, 1998. Phytochimical Methods: A guide to moderne techniques of plant analysis $3 \mathrm{e}$ ed.: chapman and hill. 1998. 303p

[14] Srivastava N, Chauhan A, Sharma B. 2012. Isolation and characterization of some phytochemicals from Indian traditional plants. Biotechnology Research International. (4): 549850 .

[15] Singleton, V. L.; Orthofer, R.; Lamuela-Raventos, R. M. 1999. Analysis of total phenols and other oxidation substrates and antioxidants by means of Folin-Ciocalteu Reagent. Methods Enzymol. 299, 152-178.

[16] Chang C, Yang M, Wen H, Chern J. 2002. Estimation of total flavonoids content in propolis by two complementary colorimetric methods. J Food Drug Analysis. 10: 178-182.

[17] Brand Williams W, Cuvelier ME, Berset C. 1995. Use of free radical method to evaluate anti-oxidant activity. Lebensmittel Wissenschaft and Technologie. 28 (1): 25-30.

[18] Prieto P, Pineda M, Anguilar M. Spectrophotometric quantitation of antioxidant capacity through the formation of a Phosphomolybdenum Complex. Specific application to the determination of Vitamin E. Anal Biochem 1999; 269: 337-341.

[19] Desai D, Raorane C, Patil S, Rajashri Gadgil and Patkar D. 2017. Anacardium occidentale: fountain of phytochemicals; the qualitative profiling. World Journal of Pharmaceutical Research. 6 (5): 585-592.

[20] Tchikaya F O, Bantsielé G B, Kouakou-Siransy G, Datté J Y, Yapo P A, Zirihi N G, Offoumou M A. 2011. Anacardium occidentale Linn. (Anacardiaceae) stem bark extract induces hypotensive and cardio-inhibitory effects in experimental animal models. Afr J Tradit Complement Altern Med. 8 (4): 452-461.

[21] Abulude, F. O., Ogunkoya, M. O. and Akinjagunla, Y. S. (2010) Phytochemical screening of leaves and stem of Cashew tree (Anacardium occidentate). Environmental Agricultural and Food Chemistry, 9, 815-819.

[22] Ifesan BOT, Fashakin JF, Ebosele F, Oyerinde AS. 2013. Antioxidant and antimicrobial properties of selected plant leaves. European Journal of Medicinal Plant. 3 (3): 465-473.

[23] Da Costa CDF, Herculano EA, Silva JCG, Paulino ET, Bernardino AC, Araújo-Júnior JX, Sant'ana AEG, Salvador MJ, Ribeiro ÊAN. 2018. Hypotensive, vasorelaxant and antihypertensive activities of the hexane extract of Anacardium occidentale linn. Arch Biol Sci. 70 (3): 459-68.

[24] Luka CD, Tijjani H, Joel EB, Ezejiofor UL, Onwukike P. 2013. Hypoglycaemic Properties of Aqueous Extracts of Anacardium occidentale, Moringa oleifera, Vernonia amygdalina and
Helianthus annuus: A Comparative Study on Some Biochemical Parameters in Diabetic Rats. International Journal of Pharmaceutical Science Invention. 2 (7): 16-22.

[25] Tsabang N, Yedjou CG, Tsambang LWD, Tchinda AT, Donfagsiteli N, Agbor GA, Tchounwou PBB and Nkongmeneck BA. 2015. Treatment of Diabetes and/or Hypertension Using Medicinal Plants in Cameroon. Medicinal \& Aromatic Plants. S2: 003.

[26] Aponjolosun SB and Fasola RT. 2020. Phytochemical, Antimicrobial and Toxicity Evaluation of Anacardium occidentale Linn. Leaf Extracts. Tropical Journal of Natural Product Research. 4 (4): 113-122.

[27] Ojezele MO and Agunbiade S. 2013. Phytochemical Constituents and Medicinal Properties of Different Extracts of Anacardium Occidentale and Psidium Guajava. Asian Journal of Biomedical and Pharmaceutical Sciences. 3 (16): 20-23.

[28] Jaiswal YS, Tatke PA, Gabhe SY and Vaidya A. 2010. Antioxidant Activity of Various Extracts of Leaves of Anacardium Occidentale (Cashew). Research Journal of Pharmaceutical, Biological and Chemical Sciences. 1 (4): 112119.

[29] Bajalan I., Mohammadi M., Alaei M., Pirbalouti A. G. 2016. Total phenolic and flavonoid contents and antioxidant activity of extracts from different populations of lavandin. Ind. Crops Prod. 87, 255-260.

[30] Da Silva R. A., Liberio S A, Do Amaral F MM, Do Nascimento F R F, Torres L M B, Neto V M, Guerra R N M (2016). Antimicrobial and Antioxidant Activity of Anacardium occidentale L. Flowers in Comparison to Bark and Leaves Extracts. Journal of Biosciences and Medicines, 4, 87-99.

[31] Sija SL, Athulya AS, Mahima MR, Vidhya A. 2019. Antioxidant and antimicrobial activity of different plant parts of Anacardium occidentale L. and Mangifera indica L.: a comparative study. International Journal of Pharmaceutical Sciences and Drug Research 2019; 11 (4): 111-115.

[32] Salehi B, Gültekin-Özgüven M, Kirkin C, Özçelik B, Morais-Braga M F B, Carneiro JNP, Bezerra CF, Silva TG, Coutinho HDM, Amina B, Armstrong L, Selamoglu Z, Sevindik M, Yousaf Z, Sharifi-Rad J, Muddathir AM, Devkota HP, Martorell M, Jugran AK, Cho WC and Martins N. 2020. Antioxidant, Antimicrobial, and Anticancer Effects of Anacardium Plants: An Ethnopharmacological Perspective. Front. Endocrinol. 11: 295.

[33] Ajileye OO, Obuotor EM, Akinkunmi EO, Aderogba MA. 2015. Isolation and characterization of antioxidant and Antimicrobial compounds from Anacardium occidentale L. (Anacardiaceae) leaf extract. Journal of King Saud UniversityScience. 27, 244-252.

[34] Razali N, Razab R, Junit SM, Aziz AA. Radical scavenging and reducing properties of extracts of cashew shoots (Anacardium occidentale). Food Chem. (2008) 111: 38-44.

[35] Tan YP and Chiang CEW 2014. Antioxidant, antityrosinase and antibacterial properties of fresh and processed leaves of Anacardium occidentale and Piper betle. Food Bioscience. 6: 17-23. 